Doi: 10.35414/akufemubid.410495

Araştırma Makalesi / Research Article

\title{
Investigation of Ring Burnished Pottery Samples from Tilbaşar Mound (Gaziantep, Turkey) Using Multiple Analysis Techniques
}

\author{
Murat Bayazit ${ }^{1}$, Osman Ekinci ${ }^{2}$ \\ ${ }^{1}$ Batman Üniversitesi, Güzel Sanatlar Fakültesi, Seramik Bölümü, Batman. \\ ID: https://orcid.org/0000-0003-1453-249X \\ ${ }^{2}$ Ankara Hacı Bayram Veli Üniversitesi, Kültür Varlıklarını Koruma Doktora Programı, Ankara. \\ ID: https://orcid.org/0000-0002-6337-8006
}

e-posta:m.bayazit@hotmail.com

\begin{tabular}{|c|c|}
\hline & Abstract \\
\hline $\begin{array}{c}\text { Keywords } \\
\text { Archaeometry; } \\
\text { Spectroscopy; } \\
\text { Characterization; Ring } \\
\text { Burnished Pottery; } \\
\text { Early Bronze Age. }\end{array}$ & $\begin{array}{l}\text { In the present study, representative samples of ring burnished ceramic findings belonging to the Early } \\
\text { Bronze Age (from Tilbaşar Mound, Gaziantep, Turkey) were archaeometrically investigated by means } \\
\text { of multiple analysis methods covering X-ray diffraction, scanning electron microscopy together with } \\
\text { energy dispersive X-ray spectrometry, optical microscopy and thermogravimetric-differential thermal } \\
\text { analysis. Additionally, the colors of the potsherds were determined by chromametric analysis. The main } \\
\text { aim of the research was to elucidate the raw material content (minerals, additional materials, if exist, } \\
\text { etc.) and production features of the findings by means of chemical, mineralogical and microscopic } \\
\text { techniques, as mentioned. The results indicated that the samples comprise carbonates suggesting use } \\
\text { of calcareous clay batches which likely refer to a regional production (when the geological features of } \\
\text { the area covering the mound are considered). Taking into account the mineral/phase content and the } \\
\text { micro structural features (poor vitrification behavior) of the samples, it was deduced that the firing } \\
\text { temperatures of the potsherds change in the range of } 700-900^{\circ} \mathrm{C} \text { which could be attributed to a } \\
\text { relatively simple firing technique (e.g. pit firing). The whole data obtained in the study brought the } \\
\text { thought that the ring burnished potteries have presumably been produced using simple techniques in } \\
\text { terms of raw material preparation and firing technology. }\end{array}$ \\
\hline
\end{tabular}

\section{Tilbaşar Höyük'te Ele Geçen Şerit Perdahlı Seramik Buluntuların Çoklu Analiz Teknikleri Kullanılarak Araştırılması}

Öz

\author{
Anahtar kelimeler \\ Arkeometri; \\ Spektroskopi; \\ Karakterizasyon; Şerit \\ Perdahlı Çömlek; Erken \\ Tunç Çă̆ı.
}

\begin{abstract}
Mevcut çalışmada Erken Tunç Çağı'na ait şerit perdahlı seramik buluntular (Tilbaşar Höyük, Gaziantep) X-ışını difraksiyonu, taramalı elektron mikroskobu/enerji saçınımlıX-ray spektroskopisi, optik mikroskop ve termogravimetrik-diferansiyel termal analiz teknikleri ile arkeometrik olarak incelenmiştir. Ayrıca, seramik buluntuların renkleri kromametrik analiz ile belirlenmiştir. Çalışmanın temel amacı buluntuların hammadde içeriklerinin (mineral, ilave malzemeler; eğer mevcut ise, vb.) ve üretim özelliklerinin kimyasal, mineralojik ve mikroskobik metotlarla aydınlatılmasıdır. Sonuçlar, numunelerin karbonatlı hammadde içerdiğini ve höyüğü çevreleyen alanın jeolojik özellikleri dikkate alındığında büyük olasılıkla bölgesel bir üretim ile ilişkilendirilebilecek kalkerli kil yataklarının kullanıldığını göstermektedir. Örneklerin mineral/faz içeriği ve mikro yapısal özellikleri (zayıf vitrifikasyon davranışı) göz önüne alındığında, seramiklerin pişirim sıcaklığının $700-900^{\circ} \mathrm{C}$ aralığında değiştiği ve bu durumun da göreceli olarak basit bir pişirme tekniğine (ör, çukurda pişirim) bağlı olduğu sonucuna ulaşılmıştır. Çalışmada elde edilen sonuçlar şerit perdahlı seramik buluntularının hammadde hazırlama ve pişirim teknolojisi bakımından basit teknikler kullanılarak üretilmiş olabilecekleri düşüncesini ortaya koymuştur.
\end{abstract}




\section{Introduction}

Tilbaşar Mound, which was discovered by an Italian crew in 1971, takes place in the vicinity of Gündoğan Village of Oğuzeli district $(20 \mathrm{~km}$ to Gaziantep province) (Fig.1) (Tilbaşar Mound Excavation Archive). Archaeological surveys and excavations have started under the supervision of Gaziantep Museum Directorate and Christine Kepinski Lecomte in 1994, but stopped in 2006. The excavations in Tilbaşar Mound restarted in 2015 under the authorization of Gaziantep Museum Directorate and scientific responsibility of Assist. Prof. Dr. Elif Genç (Çukurova University, Department of Archaeology, Turkey). Some parts of the mound were determined as the areas that would be affected by the reservoir water of the Doğanpınar Dam. During the archaeological researches in Tilbaşar, various ceramic groups have been unearthed and it was seen that they constitute an important part of the archaeological materials among the findings in the mound. Belonging to the Early Bronze Age, the ring burnished ceramic findings represent one of the characteristic pottery groups of the period (particularly the second half of that age) (Genç and Uysal, 2017; Kepinski and Bulgan, 2007).

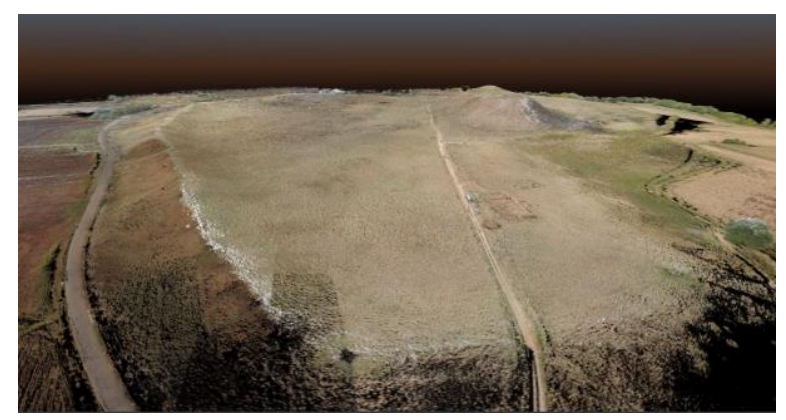

Figure 1. 3D view from Tilbaşar Mound (Tilbaşar Mound excavation archive).

The characterization process of the archaeological materials by means of multiple analysis techniques is called archaeometry in which various methods could be used, for instance; spectroscopic (i.e. Fourier transform infrared spectroscopy, X-ray fluorescence, Raman or X-ray diffraction), microscopic (transmission/scanning electron microscopy, optical microscopy) and/or thermal ones (i.e. differential scanning calorimetry, differential thermal analysis, thermogravimetric analysis) (Loehman, 1993). Thanks to its wide range of use, archaeometry comes forward as a multidisciplinary science which enables the researchers to have collaborative studies (Bayazit, 2017; Bayazit et al., 2017).

In the present study, which comprises the preliminary results of an ongoing archaeometric research (master thesis), 10 representative samples of ring burnished ceramic findings belonging to the Early Bronze Age (from Tilbaşar Mound) have been investigated by means of X-ray diffraction, scanning electron microscopy together with energy dispersive X-ray spectrometry, optical microscopy and thermogravimetric-differential thermal analysis, all of which are frequently used in ceramic archaeometry. By using these techniques, it was aimed to elucidate the raw material content (minerals, additional materials, if exist, etc.) and production features of the samples. It is predicted that the obtained results would be a directive step for further archaeometric studies to be carried on similar or contemporaneous ceramic groups in the region. Besides, the scarcity of detailed archaeometric studies on ceramics once again demonstrates the necessity of such studies.

\section{Experimental Studies}

\subsection{Sampling}

The samples (Fig.2) were selected by the head of the excavation (Elif Genç, Çukurova University) according to their representativeness. The main factors in determination process were the form, design and color of the potsherds. The samples were initially photographed by using a scale in order to record the macro views of the potsherds so as to use in the course of evaluating the results. After the documentation process, the samples were soaked in distilled water for one day in order to remove the salts (particularly the soluble ones) and soften the pollutants which might adhere on the samples' surface. Then powders were prepared by pulverizing the ceramic fractures in a porcelain mortar. At this point, the former process (purification) becomes more important, especially 
when the amount of powder to be used in some analyses is very low (i.e. in milligrams for TG/DTA).

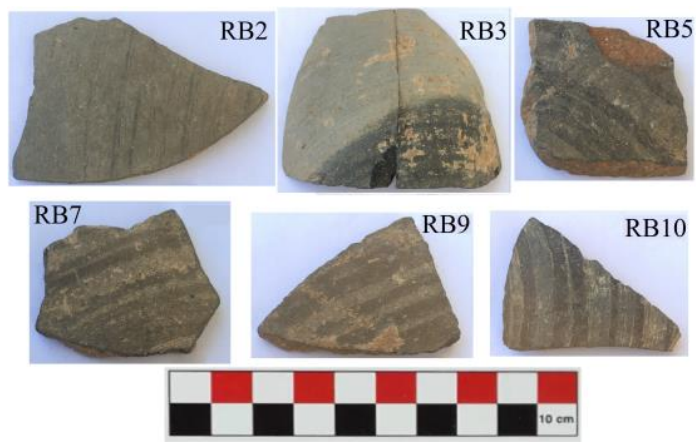

Figure 2. Representative images of some potsherds from the sample set.

\subsection{Analyses}

The micro structural and chemical content of the samples were investigated using a Carl Zeiss (Supra 40VP model) SEM/EDX. Representative potsherd fragments in appropriate size for the sample holder of the SEM-EDX device were initially prepared, and they were subsequently coated with platinum using a Q150R ES model of Qourum coating device in order to improve the conductivity so as to gain clear images. EDX results, which have been initially achieved in elemental concentration, were transformed into oxides (wt. \%) as preferred conventionally. A Rigaku Miniflex XRD (possessing $\mathrm{Cu} \mathrm{K} \alpha$ radiation) was employed with a scanning range of $2^{\circ}-70^{\circ} 2 \theta$ and a goniometer speed of $2 \%$ min in order to reveal the mineral/phases of the samples. TG/DTA analysis was carried out using a DTG-60H model of Shimadzu TG-DTA device, and the temperature was increased $20^{\circ} \mathrm{C}$ per minute. The paste features and mineral/rock content of the potsherds were examined through a polarizing microscopy (Leica Research, DMLP Model) by which both the outer and inner layers of the samples were monitored through the top and bottom illumination. The images were taken using a digital camera (Leica DFC280 comprising single and double nicol). The results were obtained through the digital imaging program Leica Qwin and interpreted by the Point Counting method. The colors of the samples were identified using a portable colorimeter running with the ColorQA Pro System III program and giving the $L, a, b$ values according to the Commission Internationale de L'Eclairage.

\section{Results}

\subsection{EDX results}

The chemical content of the samples were revealed by EDX which was simultaneously employed with SEM analysis. The results (Table 1; oxides as in wt. \% transformed from the elemental concentration; at. $\%)$ showed that the samples possess high amount of $\mathrm{CaO}$ (9.86-26.23 wt. \%) indicating utilization of calcareous raw materials. This result seems plausible when the geological structure of the region covering the area, where the mound is located, is considered. It can be seen from the geological maps of the neighboring (modern) cities that limestone (Kilis, Adıyaman, Antakya, Kahramanmaraş, Şanlıurfa), marble (Adıyaman, Osmaniye, Antakya, Kahramanmaraş, Şanlıurfa) and dolomite (Kilis) is quite abundant which may, in a way, approve the existence of raw materials rich in carbonates (web 1-7). MgO changes between 1.73 and 3.72 wt. \%. For the samples that comprise relatively high amounts of $\mathrm{MgO}$ in comparison with the others (i.e. $\geq 3.00 / 3.50$ wt. \%), it might be thought that such oxide would be originated from the dolomitic raw materials. Another source of $\mathrm{MgO}$ for the samples can be the magnesium-containing clay minerals.

Being related to the amounts of $\mathrm{CaO}$ in the samples, the amounts of $\mathrm{SiO}_{2}$ and $\mathrm{Al}_{2} \mathrm{O}_{3}$ were found to change between 45.71-63.90 wt. \% and 11.71-18.08 wt. \%, respectively. It was also found that $\mathrm{Na}_{2} \mathrm{O}$ existed in only three samples (RB2, RB5 and RB6) which might therefore include sodic plagioclases. $\mathrm{K}_{2} \mathrm{O}$ was detected for all of the samples except one (RB8). Such content, varying in the range of 0.83-4.02, suggested that the presence of potassium feldspar could also be considered for the potsherds. $\mathrm{Fe}_{2} \mathrm{O}_{3}$, which is thought to originate from the clay batches, was detected in the samples changing between 4.67 and 9.69 wt. \% (excluding RB8). The single-existence of iron mineral as a coloring oxide suggested that the decisive factor in occurrence of the colors were likely the firing technology (i.e. the maximum temperature, firing atmosphere) (see also Table 2 for the $\mathrm{L}-\mathrm{a}-\mathrm{b}$ values of the samples). $\mathrm{P}_{2} \mathrm{O}_{5}$ and $\mathrm{SO}_{3}$ 
were also detected in the samples of RB10 and RB9, respectively. The presence of such oxides was attributed to the environmental issues (agricultural activities, pollutants etc.), and thus they were thought to be the impurities which might penetrate into the porous ceramic bodies. Considering the chemical contents of the samples, it could be predicted that the potsherds should have been produced using calcareous raw materials which would have been derived from same or similar clay batches. This assumption also may indicate a local/regional production for such ceramic group.

Table 1. EDX results of the samples.

\begin{tabular}{lcccccccccc} 
Sample & \multicolumn{10}{c}{ Oxides (wt.\%) } \\
\cline { 2 - 11 } Rode & $\mathrm{SiO}_{2}$ & $\mathrm{Al}_{2} \mathrm{O}_{3}$ & $\mathrm{Fe}_{2} \mathrm{O}_{3}$ & $\mathrm{CaO}$ & $\mathrm{MgO}$ & $\mathrm{K}_{2} \mathrm{O}$ & $\mathrm{Na}_{2} \mathrm{O}$ & $\mathrm{TiO}_{2}$ & $\mathrm{SO}_{3}$ & $\mathrm{P}_{2} \mathrm{O}_{5}$ \\
\cline { 2 - 11 } RB1 & 51.50 & 12.92 & 9.69 & 20.84 & 3.68 & 1.38 & - & - & - & - \\
$\mathrm{RB} 2$ & 61.08 & 16.59 & 5.64 & 10.13 & 2.98 & 2.67 & 0.91 & - & - & - \\
RB3 & 63.90 & 16.25 & 4.67 & 9.86 & 3.32 & 2.00 & - & - & - & - \\
RB4 & 50.77 & 16.82 & 9.44 & 19.06 & 2.04 & 1.88 & - & - & - & - \\
RB5 & 50.35 & 15.47 & 8.45 & 21.34 & 2.88 & 0.83 & 0.69 & - & - & - \\
RB6 & 53.35 & 16.78 & 8.39 & 14.04 & 3.35 & 1.35 & 0.68 & 2.05 & - & - \\
RB7 & 58.21 & 16.18 & 6.81 & 12.76 & 2.95 & 1.91 & - & 1.19 & - & - \\
RB8 & 59.79 & 18.08 & - & 18.42 & 3.72 & - & - & - & - & - \\
RB9 & 52.09 & 16.99 & 7.98 & 14.73 & 2.42 & 4.02 & - & 1.53 & 0.24 & - \\
RB10 & 45.71 & 11.71 & 7.39 & 26.23 & 1.73 & 1.59 & - & - & - & 5.64 \\
\hline
\end{tabular}

-: not detected or under the detection limit.

Table 2. Results of chromametric analysis.

\begin{tabular}{lllll} 
Sample & L & a & b & Color \\
\hline RB1 & 25,7187 & 2,9706 & 7,9829 & Brown \\
RB2 & 26,5729 & 2,4597 & 11,8164 & Brown \\
RB3 & 20,5375 & $-2,0499$ & 7,8185 & Brown \\
RB4 & 18,7121 & 20,4159 & 7,3750 & Brown \\
RB5 & 19,8992 & 10,1654 & 14,7157 & Brown \\
RB6 & 14,0315 & 3,1889 & 3,4349 & Brown \\
RB7 & 19,7774 & 4,8561 & 8,2717 & Brown \\
RB8 & 10,1310 & 3,1445 & 6,3887 & Brown \\
RB9 & 15,5465 & 3,0550 & 7,7699 & Brown \\
RB10 & 15,0054 & 4,8028 & 7,7561 & Brown \\
\hline L:
\end{tabular}

L: 0/100; white/black. a: 0/-60; green and 0/+60; red. b: 0/-60; blue and 0/+60; yellow intensity.

\subsection{Mineral/phase characterization}

After revealing the chemical composition of the samples, XRD was employed in order to enlighten the mineralogical content of the potsherds. The results (Table 3 ) showed that quartz and calcite existed in all of the samples and they were occasionally the major phases. In most of the samples, calcite was found to be the dominant mineral indicating usage of calcareous raw materials. This prediction was seen to be compatible with the amounts of $\mathrm{CaO}$ (9.86-26.23 wt. \%; conventionally transformed from $\mathrm{Ca}$ detected by EDX), since such amounts of $\mathrm{CaO}$ are mostly related with the presence of carbonates indicating calcareous raw material (Javanshah, 2018). Feldspar and/or plagioclases were also detected for the samples some of which included only trace or scarce amounts. The low intensities of feldspar/plagioclase minerals are thought to result in low or none vitrification degree (that will be addressed in electron microscopy results through the SEM images), since they behave as a flux which may reduce the formation temperature of the viscous silicate liquid throughout the ceramic matrix in the course of the firing process, and therefore might trigger the vitrification phenomenon by also lowering its occurrence temperature (Javanshah, 2018; Iloghalu and Nnuka, 2014).

For three of the samples, some neo-formations were revealed. Gehlenite, which may form by the reaction of the carbonates and silicates (clay minerals) at about $800^{\circ} \mathrm{C}$ (Cultrone et al., 2001), was seen on XRD patterns of the samples RB1 (trace), RB2 (trace) and RB3. Pyroxene, which could occur through the reaction between the carbonates and silica around $850^{\circ} \mathrm{C}$ (Issi, 2012), was detected for the samples RB1 (scarce) and RB3 (trace). The presence of these high temperature minerals suggested that such samples were presumably exposed to higher temperatures when compared to the others which evidently comprise primary calcite and do not 
include any neo-formations. On the other hand, the simultaneous existence of calcite was also detected for the samples comprising the neo-formations. This residual was assigned to the secondary calcite that may have subsequently emerged in the ceramic matrix owing to the burial conditions (Shoval et al., 1993; Fabbri et al., 2014). In brief, the firing temperature ranges of the samples were found to be $700-900^{\circ} \mathrm{C}$. In particular, it was revealed that while most of the potsherds were fired at about $700-800^{\circ} \mathrm{C}$, three samples (RB1, RB2 and RB3) should have been subjected to a relatively higher temperature $\left(800 / 850-900^{\circ} \mathrm{C}\right)$. For both cases, taking into account the relative abundance of the minerals (especially the neo-formations), it is yet predicted that a simple firing technique would have been used.

Table 3. XRD results of the samples.

\begin{tabular}{lllllllll} 
& \multicolumn{1}{c}{ Mineral/Phase } & & & & \\
\cline { 2 - 6 } Code & Q & Cal & F/PI & C & G & P & H & T $\left({ }^{\circ} \mathrm{C}\right)$ \\
\hline RB1 & $\bullet \bullet$ & $\bullet$ & $\bullet$ & tr & tr & s & tr & $800-900$ \\
RB2 & $\cdots \cdots$ & $\cdots$ & $\cdots$ & $\bullet$ & tr & - & s & $800-900$ \\
RB3 & $\cdots \cdots$ & $\bullet$ & $\cdots$ & $\bullet$ & $\bullet$ & tr & tr & $850-900$ \\
RB4 & $\bullet$ & $\cdots \cdots$ & tr & tr & - & - & - & $750-800$ \\
RB5 & $\bullet$ & $\cdots \cdots$ & tr & $\bullet$ & - & - & - & $700-800$ \\
RB6 & $\cdots$ & $\cdots \cdots$ & $\cdots \bullet$ & $\bullet$ & - & - & - & $700-800$ \\
RB7 & $\bullet$ & $\cdots \cdots$ & sc & tr & - & - & - & $700-800$ \\
RB8 & $\bullet$ & $\cdots \cdots$ & $\bullet$ & $\bullet$ & - & - & - & $700-800$ \\
RB9 & $\bullet$ & $\cdots \cdots$ & sc & tr & - & - & - & $700-800$ \\
RB10 & $\cdots$ & $\cdots \cdots$ & sc & s & - & - & - & $750-800$
\end{tabular}

•: Relative abundance (considering the intensity/counts), tr: trace amount, -: not defined. Q: quartz, Cal: calcite, F/PI: feldspar/plagioclase, C: clay mineral (illite/muscovite), G: gehlenite, P: pyroxene $\mathrm{H}$ : hematite, $\mathrm{T}$ : Estimated firing temperature $\left({ }^{\circ} \mathrm{C}\right)$

Hematite was also found on XRD pattern of some samples; RB1 (trace), RB2 (scarce) and RB3 (trace). The appearance of hematite (which was also detected by EDX in elemental concentration as Fe and transformed into oxide form, except for RB8) indicated that such samples would have been exposed to oxidizing atmosphere or the firing environment was oxidative at least during the last stages of the firing process (Issi et al., 2011; Bayazit et al., 2016). It was seen that the XRD results wellmatched with the EDX data in general. A slight inconsistency between the mineralogical and chemical contents of few samples could be attributed to the fact that EDX was carried out on thin sectional areas of the samples (that could have been applied on a heterogeneous surface in the course of the analysis), whereas XRD was employed on sample powders homogenously ground. For instance, although $\mathrm{K}$ and Fe were not detected by EDX applied on the sectional area of the sample RB8, these elements were separately observed on different selected areas on SEM image of the same sample approving the prediction above.

\subsection{Optical microscopy results}

Petrography results showed that the samples could be classified into five groups when the mineral/rock, porosity and aggregate contents of the potsherds are taken into account (Table 4). Quartz was detected in all of the samples while plagioclase and calcite were established in vast majority of the sample set excluding the fourth group (RB7 and RB9) and the first group (RB1, RB2 and RB3), respectively. Opaque minerals and pyroxene were occasionally found in the sample set. Biotite, a phyllosilicate mineral, was seen in the samples of the first group. Consisted of fine silica grains, chert (sedimentary rock formation) was detected in the samples excluding the fourth group (RB7 and RB9). Andesite and basalt were identified in the first and third group, respectively. Limestone was seen in most of the samples including the third, fourth and fifth group. Marble was detected for the samples belonging to the fourth group in which brick fractures (vol. \%1) were also found. 
Table 4. Petrography results of the samples.

\begin{tabular}{|c|c|c|c|c|}
\hline $\begin{array}{l}\text { Sample } \\
\text { groups }\end{array}$ & $\mathrm{P}(\%)^{*}$ & $\operatorname{MTA}(\%)^{*}$ & Mineral/rock** & Description \\
\hline Group-1 & 5 & 45 & $\mathrm{Q}, \mathrm{PI}, \mathrm{Bi}, \mathrm{Py}, \mathrm{Op}, \mathrm{Ch}, \mathrm{A}$ & $\begin{array}{l}\text { Consisted of medium sized aggregates of } \\
\text { andesitic rock origin }\end{array}$ \\
\hline Group-2 & 6 & 35 & $\mathrm{Q}, \mathrm{C}, \mathrm{PI}, \mathrm{Py}, \mathrm{Op}, \mathrm{Ch}$ & $\begin{array}{l}\text { Consisted of coarse aggregates of sandstone } \\
\text { rock origin }\end{array}$ \\
\hline Group-3 & 8 & 25 & $\mathrm{Q}, \mathrm{C}, \mathrm{Pl}, \mathrm{Py}, \mathrm{B}, \mathrm{L}, \mathrm{Ch}$ & $\begin{array}{l}\text { Consisted of medium sized aggregates of } \\
\text { basaltic rock origin }\end{array}$ \\
\hline Group-4 & 2 & 40 & $\mathrm{Q}, \mathrm{C}, \mathrm{M}, \mathrm{L}, \mathrm{BF}(\% 1)$ & $\begin{array}{l}\text { Consisted of coarse aggregates of marble rock } \\
\text { origin }\end{array}$ \\
\hline Group-5 & 5 & 32 & $\mathrm{Q}, \mathrm{C}, \mathrm{Pl}, \mathrm{Op}, \mathrm{L}, \mathrm{Ch}$ & $\begin{array}{l}\text { Consisted of fine aggregates of sandy } \\
\text { limestone rock origin }\end{array}$ \\
\hline
\end{tabular}

(*) P: Porosity (vol. \%), MTA: Matrix Total Aggregate (vol. \%), (**) A: Andesite, B: Basalt, Bi: Biotite, C: Calcite, Ch: Chert, L: Limestone, M: Marble, Op: Opaque minerals, Pl: Plagioclase, Py: Pyroxene, Q: Quartz, BF: Brick fractures Fine/Medium/Coarse Aggregate: $<0,5 / 0,5-1,0 />1,0$ (mm).

Group-1: RB1, RB2, RB3; Group-2: RB4; Group-3: RB5, RB6, RB8; Group-4: RB7, RB9; Group-5: RB10

It was anticipated that the petrographic investigation covering the mineral/rock contents of the samples would be compatible with the results of chemical and mineralogical analyses (XRF and XRD), which mainly indicated the calcareous raw materials, and may reveal the existence of carbonates. In general, the carbonate bearing mineral (i.e. calcite) or rocks (i.e. limestone, marble) were determined. For some of the samples, in which such type of contents were occasionally missing (i.e. Group-1 or Group-2), it was predicted that the possible limitation in detecting the mineral and/or rock type in the course of the analysis was due to the finely dispersed grains through the matrices of some ceramics. Taking into account the mineral/rock content of the samples, it was assumed that the raw materials used for the potsherds generally correspond to the igneous and sedimentary rocks, and this indicates use of local/regional sources which matches with the geological structure of the studied area and its vicinity (web 1-7).

The samples were additionally examined through a polarizing microscopy in order to investigate the ceramic paste. It was seen from the microphotographs of some samples (i.e. RB2; Fig 3b,
RB10; Fig 3j) that there was a color transition which was thought to occur due to an unstable firing condition or heterogeneous grain distribution both of which may indicate an inelaborate manufacture. Considering the size of the grains in ceramic matrices, the images showed that most of the samples had moderate or high ratio of non-plastic material/matrix. It is foreseen that this phenomenon emerged due to the relatively coarser calcite grains which were also observed in microphotographs of some samples (RB4, RB5, RB6, RB7 and RB9; Fig 3d, Fig 3e, Fig 3f, Fig 3g and Fig 3i, respectively). Secondary calcite, which is presumed to occur as the reformed calcite during the burial time (Shoval et al., 1993; Fabbri et al., 2014), was additionally seen for the samples of RB1, RB2, RB4, RB5, RB6 and RB8 (Fig 3a, Fig 3b, Fig 3d, Fig 3e, Fig $3 f$ and Fig $3 h$, respectively). It was also observed that secondary calcite has filled some gaps (e.g. RB4, RB5 and RB6; Fig 3d, Fig 3e, Fig 3f) in the ceramic matrix which are presumed to arise during the firing process (i.e. removal of organics). Finally, some grog fragments were seen in microphotographs of some samples (RB4, RB5, RB6 and RB8; Fig 3d, Fig 3e, Fig $3 f$ and Fig $3 h$, respectively) and this type of residuals are assigned to use of the production rejects, or the clay lumps (Rice, 1987; Loftfield, 1976; Safer, 1979). 


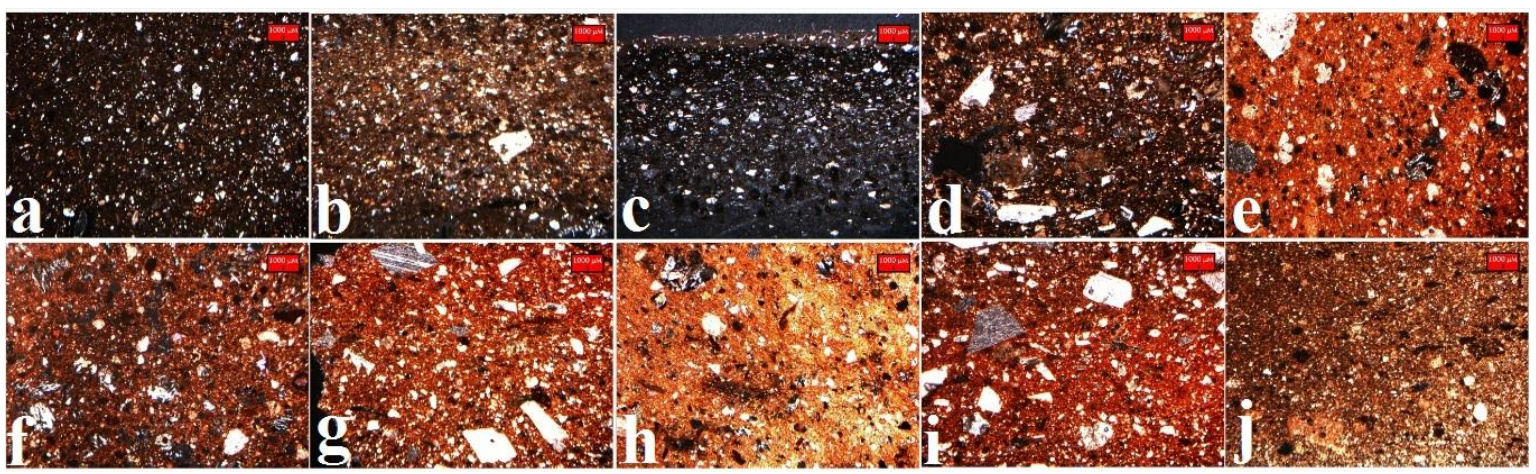

Figure 3. Microphotographs of the samples.

\subsection{TG-DTA results}

In thermogravimetric-differential thermal analysis (TG-DTA) the changes occurring in ceramic samples during a controlled temperature increase can be observed (Drebushchak et al., 2005). While DTA curves indicate the endothermic and exothermic effects (occurring as a result of enthalpy change in ceramics depending on the temperature increase), TG curves (emerging due to such endothermic - exothermic reactions) exhibit the weight losses in the samples (Palanivel and Kumar, 2011). Through the data obtained in the analyses, many contents such as the presence of hygroscopic water, chemical water, iron hydroxide/oxyhydroxide, carbonates (calcite, dolomite etc.), decomposition of organics, solid phase transformation and polymorphic changes can be identified by their characteristic endothermic or exothermic responses at different temperature ranges (Drebushchak et al., 2005; Palanivel and Kumar, 2011; Moropoulou et al., 1995; Velraj et al., 2010; Franquelo et al., 2008; Maritan et al., 2006; De Nobili and Maggioni, 1993).

Within this framework, the changes in the ceramic fabrics depending on the temperature increase would be evaluated in archaeometric way in the present study. TG-DTA curves of some representative samples are given in Fig. 4-7. It was seen from the obtained results that while the total weight loss was low (3-10\% wt.) for the samples of RB-1, RB-2 and RB-3, it was quite high (16-26 \% wt.) for the rest of the samples. This result suggests that the samples of TB 1-3 would have been subjected to higher temperature in comparison with the other samples (Meyvel et al., 2012; Krapukaitytè et al., 2008).

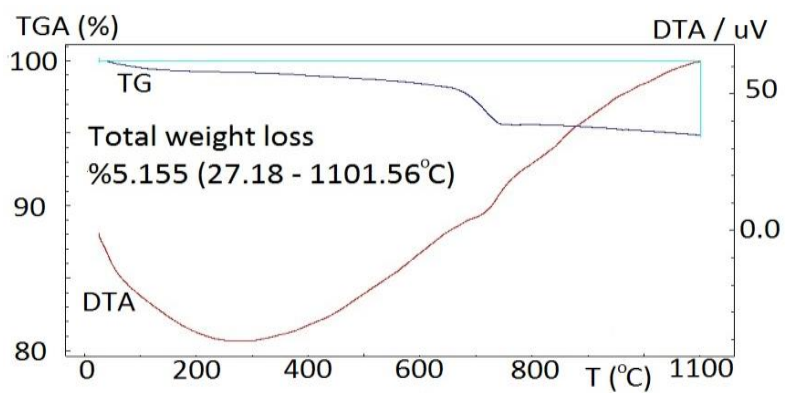

Fig 4. TG-DTA analysis of the sample RB1.

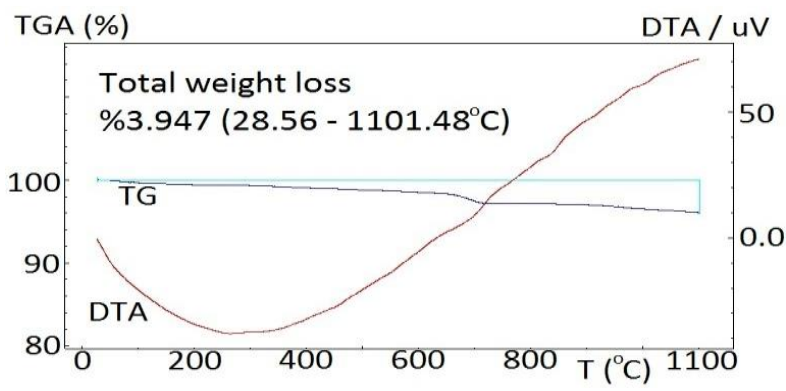

Fig 5. TG-DTA analysis of the sample RB3.

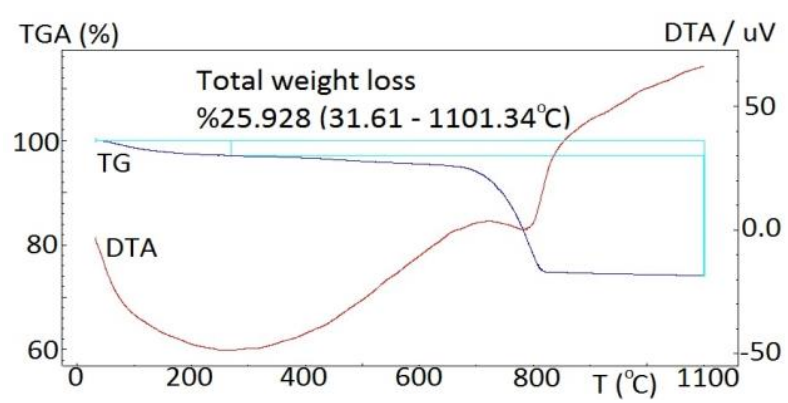

Fig 6. TG-DTA analysis of the sample RB7.

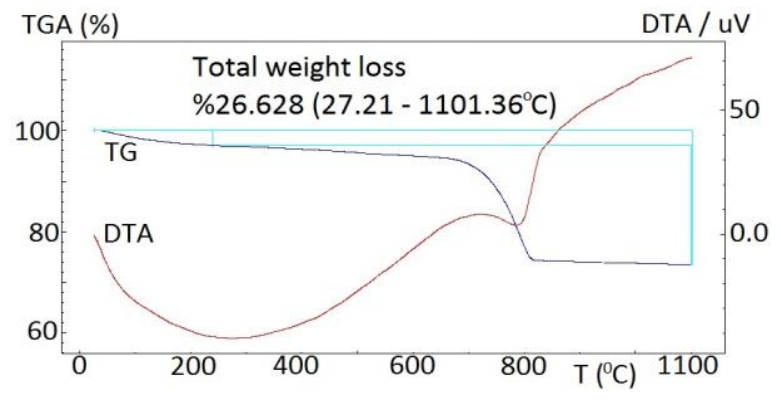

Fig 7. TG-DTA analysis of the sample RB9. 
The affinity observed at the temperature ranges of the weight losses and decomposition of carbonates indicated that the ceramics would mostly have been produced using calcareous clay deposits (Meyvel et al., 2012). In this context, when the DTA curves of the ceramics are considered; the ignorable endothermic effect about $700-750^{\circ} \mathrm{C}$ observed for the first three samples suggested the existence of secondary calcite in the samples (Fabbri et al., 2014). The endothermic effect for the other samples was evidently determined around $800-850^{\circ} \mathrm{C}$ in average. It is predicted that the secondary calcite in the ceramic findings would have occurred due to the burial conditions, as formerly mentioned (Fabbri et al., 2014; Shoval et al., 1993). The ignorable changes on DTA and TG curves over $900^{\circ} \mathrm{C}$, which may imply the polymorphic transformations, suggested that the ceramics presumably were not fired at higher temperatures and the sinterization behavior of the samples was relatively low (Krapukaitytè et al., 2008).

\subsection{SEM results}

SEM analysis in the present study allowed elucidating the micro structural features of the samples. In general, it was seen from the SEM images that the samples have low vitrification degree (Fig 8a; partial vitrification identified by the smooth surfaces with relatively arranged pores in the ceramic matrix) and even none for most of them (e.g. Fig 8 b-d). Due to the presence of neoformations detected for some of the samples through XRD analysis (see Table 3), it was expected that there could be a vitrification and/or sinterization behavior thanks to the higher firing temperature at which gehlenite and/or pyroxene would appear, however smooth surfaces and/or arrangement of the pores were vaguely or partially observed (Fig 8a). That result again proved that the firing temperature ranges of such potsherds should not have exceeded $950-1000^{\circ} \mathrm{C}$. Additionally, the laminar structure of the clay minerals, which decompose at about $900^{\circ} \mathrm{C}$ (Cultrone et al., 2001), were also seen (Fig 8c). The occurrence of this phenomenon might be attributed to an uneven firing circle which would be assigned to a simple production technology in which an adequate temperature range for generating a compact matrix has presumably not been supplied.

Secondary calcite was detected by XRD and petrography. This residual was additionally observed through the SEM images of some samples (i.e. RB2; Fig 9). The evident contrast difference in the image implied that secondary calcite has penetrated into the porous structure of the pottery and occasionally covered the texture and filled the gaps. This prediction was also approved by the EDX spectra taken from different parts of the SEM image. EDX scanning showed that while the amount of $\mathrm{CaO}$ was relatively low throughout the ceramic matrix (5.19 and 6.38 wt. $\%$ for the spectrum-2 and spectrum-3, respectively), it was found to be intensively higher in particular areas of the ceramic matrix of RB2 (CaO: 62.84 wt. \%, spectrum-1).

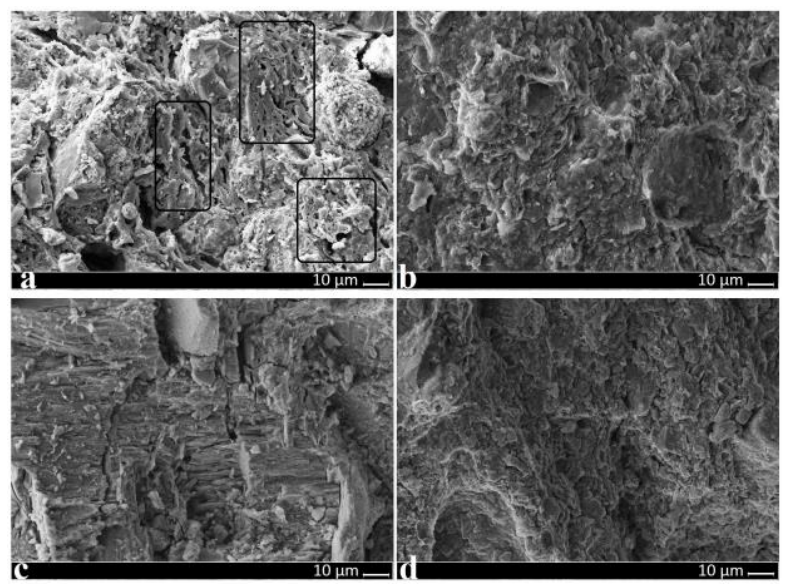

Fig 8. SEM images of the samples (a) RB1, (b) RB5, (c) RB6 and (d) RB7. 


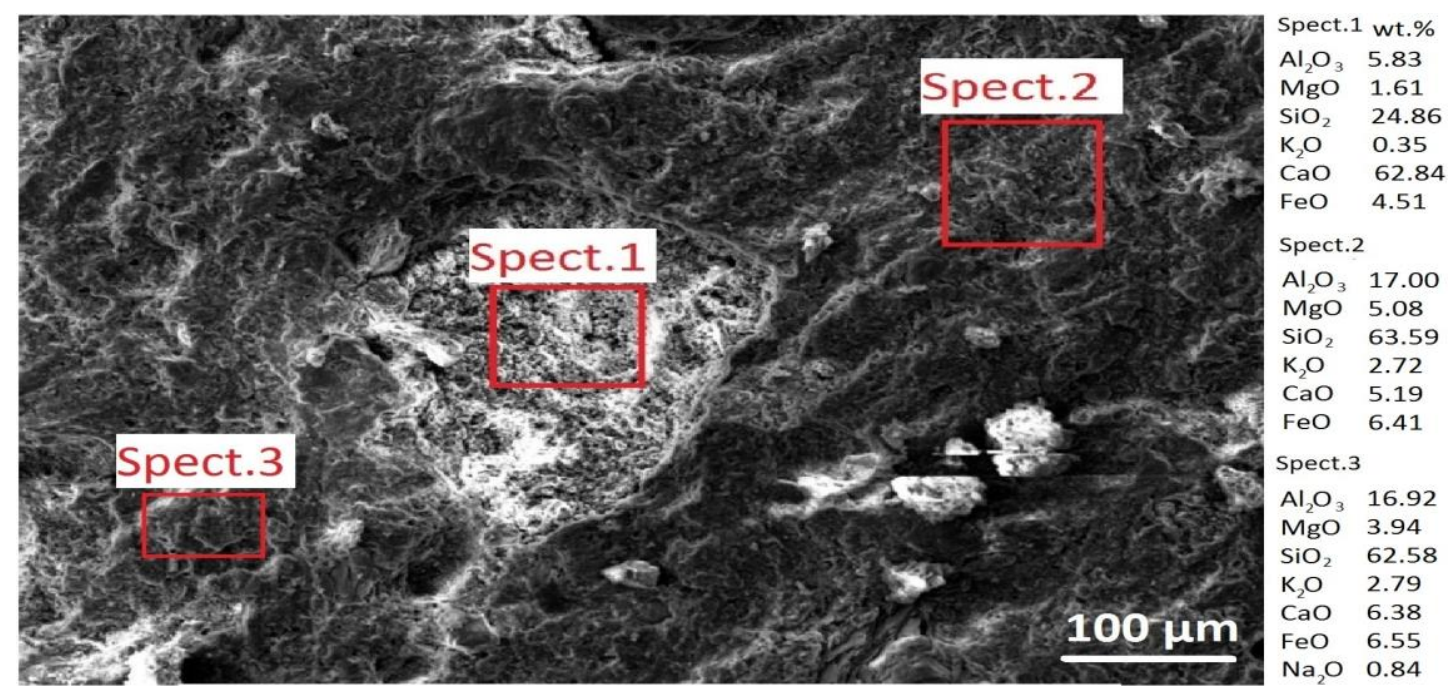

Fig 9. EDX spectra of selected regions on SEM image of sample RB2.

\section{Conclusions}

The data obtained in framework of the present study provided a useful knowledge regarding the ring burnished ceramic findings belonging to the Early Bronze Age (from Tilbaşar Mound, Gaziantep, Turkey). The results showed that the potters would have used calcareous raw materials which likely have been supplied locally. The geological features of the area covering the mound also approved this assumption thanks to the mineralogical affinity in terms of mainly the presence of carbonates (i.e. limestone, marble) in the neighboring (modern) cities. The firing temperature range of the samples were found to change between $700-900^{\circ} \mathrm{C}$ which could be attributed to a relatively simple firing technique (i.e. pit firing). This temperature range was additionally confirmed by the complementary analyses (i.e. SEM-EDX and TG-DTA). Considering the whole data in terms of raw material preparation and firing technology, it was deduced that the ring burnished potteries have presumably been produced using simple techniques. It is believed that the results of this research would be one of the important parts of archaeometric studies regarding the characterization of ceramic findings belonging to the same or different age/region.

\section{Acknowledgements}

The authors gratefully thank Assist. Prof. Dr. Elif Genç (Çukurova University) for providing the ceramic samples and contributing to the Introduction. We also thank Prof. Dr. Metin Ak (Pamukkale University), Assoc. Prof. Dr. Ali İssi (Kütahya Dumlupınar Universtiy) and Assoc. Prof. Dr.
Ali Akın Akyol (Ankara Hacı Bayram Veli University) for their support to the analyses carried out within this study. This paper includes the data obtained within the master thesis of Osman Ekinci submitted to Batman University, Institute of Science, Department of Archaeometry (2018).

\section{References}

Bayazit, M., 2017. Ceramic Petrography in Archaeometry. Batman University Journal of Life Sciences, 7 (2), 3644.

Bayazit, M., Işık, I., Uz, V., Coşkun N.D. and Issi, A., 2017. An interdisciplinary approach in science: archaeometric applications for ceramics. $11^{\text {th }}$ International Eskişehir Terracotta Symposium, Eskişehir, Turkey, 2017, 443-448.

Bayazit, M., Isik, I., Issi, A. And Genc, E., 2016. Archaeometric investigation of the Late ChalcolithicEarly Bronze Age I and the 1st-2nd millennium BCE potteries from Kuriki-Turkey. Applied Clay Science, 126, 180-189.

Cultrone, G., Rodriguez-Navarro, C., Sebastian, E., Cazalla, O. and De La Torre, M.J., 2001. Carbonate and silicate phase reactions during ceramic firing. Eur. J.Mineral., 13, 621-634.

De Nobili, M. and Maggioni, A., 1993. Influenza della sostanza organica sulle proprietà fisiche del suolo. In: Nannipieri, P. (Ed.), Ciclo della Sostanza Organica nel Suolo, 4354.

Drebushchak, V.A., Mylnikova, L.N., Drebushchak, T.N. and Boldyrev, V.V., 2005. The investigations of ancient pottery. Journal of Thermal Analysis and Calorimetry, 82, 617-626. 
Fabbri, B., Gualtieri, S. and Shoval, S., 2014. The presence of calcite in archeological ceramics. J. Eur. Ceram. Soc., 34, 1899-1911.

Franquelo. M.L., Robador. M.D., Ramirez-Valle. V, Duran. A, Jimenez de Haro. M.C., and Perez- Rodriguez. J.L., 2008. Roman ceramic of hydraulic mortars used to build the mithraeum house of merida (Spain). J. Thermal Anal. Calorimetry, 92, 331-335.

Genç E. and Uysal T., 2017. Doğanpınar Barajı Tilbaşar Höyük 2015 yılı kazısı, 38. Uluslar arası Kazı, Araştırma ve Arkeometri Sempozyumu Toplantısı, Edirne, Türkiye, 23-27 Mayıs, 2016, Vol.1, 293-304.

Iloghalu, F.I. and Nnuka, E.E., 2014. Evaluation of the Fluxing Potentials of Okene Potassium Feldspar for Silicate Ceramics Production, Journal of Multidisciplinary Engineering Science and Technology (JMEST), 1 (4), 288-299.

Issi, A., 2012. Estimation of ancient firing technique by the characterization of semi-fused Hellenistic potsherds from Harabebezikan/Turkey. Ceram. Int., 38, 2375-2380.

Issi, A., Raškovska, A., Kara, A., Grupce, O., MinčevaŠukarova, B. and Okyar, F., 2011. Scanning electron microscopy and micro-Raman spectroscopy of slip layers of Hellenistic ceramic wares from Dorylaion/Turkey. Ceram. Int., 37, 1879-1887.

Javanshah, Z., 2018. Chemical and Mineralogical Analysis for Provenaning of the Bronze Age Pottery from Shahr-I-Sokhta, South Eastern Iran, Scientific Culture, 4 (1), 83-92.

Kepinski, C. and Bulgan, F., 2007. Research at Tilbeshar in 2005 City from the Early and Middle Bronze Ages. 28. Kazı Sonuçları Toplantısı 2. Cilt (2007) (29 Mayıs-2 Haziran 2006 Çanakkale), 733-742.

Krapukaitytè, A., Tautkus, S., Kareiva, A. and Zalieckienè, E., 2008. Thermal analysis-a powerful tool for the characterization of pottery. Chemija, 19, 4-8.

Loehman, R.E., 1993. Characterization of Ceramics, Butterworth-Heinemann, Reed-Elsevier Inc., 312 p.

Loftfield, T.C., 1976. A Brief and True Report: An Archaeological Interpretation of the Southern North Carolina Coast (Unpublished Ph.D. dissertation) Department of anthropology, University of North Carolina, Chapel Hill.

Maritan, L., Nodari, L., Mazzoli, C., Milano, A. and Russo, U., 2006. Influence of firing conditions on ceramic products: Experimental study on clay rich in organic matter. Applied Clay Science, 31, 1-15.

Meyvel, S., Sathya, P. and Velraj, G., 2012. Thermal characterization of archaeological pot sherds recently excavated in Nedunkur, Tamilnadu, India. Cerâmica, 58, 338-341.

Moropoulou, A., Bakolas, A. and Bisbikou, K., 1995. Thermal analysis as a method of characterizing ancient ceramic Technologies. Thermochimica Acta, 2570, 743-753.

Palanivel, R. and Kumar, U.R., 2011. Thermal and spectroscopic analysis of ancient potteries. Rom. Journ. Phys., 56, 195-208.

Rice, P.M., 1987. Pottery analysis: A sourcebook, University of Chicago Press, Chicago.

Saffer, M., 1979. Aboriginal Clay Resource Utilization of the Georgia Coast (M.A. thesis) Department of anthropology, University of Florida, Gainesville.

Shoval, S., Gaft, M., Beck, P. and Kirsh, Y., 1993. The thermal behavior of limestone andmonocrystalline calcite tempers during firing and their use in ancient vessels. J. Therm. Anal., 40, 263-73.

Tilbaşar Mound Excavation Archive.

Velraj, G., Sudha, R. and Hemamalini, R., 2010. X-Ray Diffraction and Tg-Dta studies of archaeological artifacts recently excavated in Salamankuppam Tamilnadu. Recent Research in Science and Technology, 2(10), 89-93.

1- http://www.mta.gov.tr/v3.0/sayfalar/hizmetler/madenharitalari/gaziantep.pdf (15.03.2018)

2- http://www.mta.gov.tr/v3.0/sayfalar/hizmetler/madenharitalari/kilis.pdf (15.03.2018)

3- http://www.mta.gov.tr/v3.0/sayfalar/hizmetler/madenharitalari/adiyaman.pdf (15.03.2018)

4- http://www.mta.gov.tr/v3.0/sayfalar/hizmetler/madenharitalari/osmaniye.pdf (15.03.2018)

5- http://www.mta.gov.tr/v3.0/sayfalar/hizmetler/madenharitalari/Antakya.pdf (15.03.2018)

6- http://www.mta.gov.tr/v3.0/sayfalar/hizmetler/madenharitalari/kahramanmaras.pdf (15.03.2018)

7-http://www.mta.gov.tr/v3.0/sayfalar/hizmetler/madenharitalari/sanliurfa.pdf (15.03.2018) 